\title{
Non-invasive detection of colorectal cancer - do we still need the guaiac-based fecal occult blood test? ${ }^{1)}$
}

\author{
Jürgen Stein ${ }^{1,2, *}$, Stefan M. Loitsch ${ }^{2}$ and \\ Yogesh Shastri \\ 1 Department of Gastroenterology and Clinical Nutrition, \\ Katharina Kasper Hospitals, Johann Wolfgang Goethe- \\ University, Frankfurt am Main, Germany \\ ${ }^{2}$ Katharina Kasper Institute of Preventive Medicine and \\ Clinical Nutrition, Frankfurt am Main, Germany
}

\begin{abstract}
Given the simplicity of the method and how it can be applied, as well as proof that it lowers the mortality rate, fecal occult blood testing (FOBT) is currently the most commonly used screening method for colorectal cancer (CRC). However, the test suffers from poor sensitivity, particularly with respect to detecting early stages, as well as low acceptance among the population. Preliminary data on detecting calprotectin and tumour-M2-PK in the stool indicated that a better screening performance could be expected. But these tests also suffer from low sensitivity in detecting early stages and from poor specificity, thus limiting the usefulness of the tests as a result of high follow-up costs. Recently developed immunological tests (I-FOBT) demonstrate significantly increased sensitivity and specificity. I-FOBTs use antibodies specific to human hemoglobin and are therefore not affected by diet and drugs, leading to improved patient partipication. At present, I-FOBTs seem to be the most cost-effective approach for non-invasive screening. The detection of tumour-DNA in the stool opens up a new era in early diagnosis of colorectal cancer. Small trials have pointed to a very high sensitivity of these methods: $62-91 \%$ for colorectal cancer and between $26 \%$ and $73 \%$ for adenomas, with a very high level of specificity (93-100\%). The major drawback of this type of testing, compared with other screening tests available today, is its high cost.

\footnotetext{
1)Original German online version at: http://www.referenceglobal.com/doi/pdf/10.1515/JLM.2008.021.

The German article was translated by Compuscript Ltd. and authorized by the authors.

${ }^{*}$ Correspondence: Prof. Dr. Dr. Jürgen Stein, Gastroenterologie/ Diabetologie/Ernährungsmedizin, St. Elisabethen-Krankenhaus der Katharina Kasper Kliniken, Lehrkrankenhaus der J.W.

Goethe-Universität Frankfurt, Ginnheimer Str. 3, 60487

Frankfurt/Main, Germany

Tel.: + 49 (69) 79392119/2219

Fax: + 49 (69) 7939266
}

E-mail: J.Stein@em.uni-frankfurt.de
\end{abstract}

Keywords: calprotectin; colon cancer; colorectal cancer; DNA; fecal occult blood test; M2-PK.

The incidence of colorectal cancer (CRC) doubled between 1960 and 1980 [1]. In statistics on cancer-related deaths in Germany, colorectal cancer is the second most common cause, right after bronchial cancer but still ahead of breast cancer. Each year Germany sees more than 70,000 new cases, with almost 35,000 people dying from this type of cancer each year. The lifetime risk in Germany is $4-6 \%$; from age 50 , incidence and mortality rates double with each life decade. Given the long-term process of cancerous degradation, it is possible to prevent cancer through adequate screening and polypectomy or, at least, to detect the tumour in an early stage so as to allow for effective countermeasures to be taken.

Total colonoscopy is seen as the diagnostic "gold standard" around the world when it comes to the early detection of colorectal cancer, as this allows for the simultaneous removal of potentially malignant preliminary stages of cancer. However, this method is still met with limited acceptance among patients, due to, most likely, the preparatory laxative measures as well as physical stress and sedation [2].

The alternative is fecal occult blood testing (FOBT), which Germany added to its early detection programme for cancer in 1977. The benefit of FOBT has been proved repeatedly in a variety of large-scale multicentre randomised studies. Still, due to its poor sensitivity, this test is of limited use. As a result, other non-invasive tests have been developed since the mid-1990s, based on different approaches. Apart from immunology-based FOBTs, these include, for example, the detection of additional blood components, such as leucocyte proteins (calprotectin, lactoferrin), albumin, acute-phase proteins ( $\alpha 1$ antitrypsin), tumour-specific metabolic proteins (pyruvate kinase M2) as well as various proto-oncogenes and oncogenes. The following article attempts to provide a critical analysis of the current situation of the most important new fecal tests based on the literature.

\section{Fecal occult blood test}

Fecal testing for occult blood is based on the observation that colorectal carcinomas are more likely to bleed than 
normal intestinal mucosa. Since many carcinomas bleed intermittently, repeated testing can result in a more reliable detection [3,4]. A positive FOBT should not be checked; instead, it calls for an examination of the entire colon by means of a colonoscopy.

\section{Guaiac tests}

The most common tests, such as the hemoccult test, use filter papers treated with guaiacum resin. The pseudoperoxidase activity of any hemoglobin in the stool sample makes the guaiacum resin turn blue after hydrogen peroxide has been added. The sensitivity in detecting colorectal cancer has been studied in different groups using large populations under screening conditions. For patients with known symptomatic carcinomas, the sensitivity of a single test is over $90 \%$ in individual studies [5].

In a prospective study a complete colonoscopy was performed on 3,000 individuals without symptoms and an average age of 63 following an FOBT. The sensitivity of the FOBT in this case was $50 \%$ for carcinomas, $12 \%$ for all adenomas and 22\% for high-risk adenomas (tubular adenomas $>1 \mathrm{~cm}$, villous parts or severe dysplasia) [5]. The specificity of the FOBT used was at $94 \%$.

To increase the sensitivity, the test areas were rehydrated for this study prior to its development. However, the increase in sensitivity thus achieved (from $80.8 \%$ to $92.2 \%$ ) was combined with a significantly lower specificity (from $97.7 \%$ to $90.4 \%$ ). As a result, in the US, at least, it is not recommended to rehydrate the test packets [6, 7]. The sensitivity for colorectal cancer is at around $40 \%$ with a specificity of between $96 \%$ and $98 \%$ in a single, non-rehydrated hemoccult test consisting of three test slides [8].

Four large prospective randomised studies have been carried out, whose data on lowering mortality are now available (Table 1). When applied annually, the FOBT can produce a reduction in CRC-associated mortality of $16-33 \%$, since tumours are detected at a stage of a more favourable prognosis. A recent update to the Minnesota study also showed, for the first time, a lower incidence after 18 years of observation. The decrease in incidence amounted to $20 \%$ in the annually tested group, as compared to $17 \%$ in the biennial tested group [9].

The sensitivity of FOBT for adenomas is significantly lower than for cancer. It correlates with the size of the adenoma and the related increase in the tendency to bleed. In an endoscopically controlled study, sensitivity was merely $24 \%$ [5].

\section{Immunological testing to detect occult blood}

The benefit of using chemically-based FOBTs is limited by a variety of factors. Apart from moderate sensitivity, as already mentioned, it is frequently dietary factors (e.g., consumption of meat and meat products) that lead to false positive findings [10]. Compliance with certain dietary recommendations, however, reduces the acceptance of the tests [11]. These problems can be avoided by using immunochemical FOBTs (I-FOBTs). These methods were introduced in the early 1990s and detect either hemoglobin or haptoglobin in the stool (Table 2). Another advantage of I-FOBTs is the quantitative analysis of hemoglobin. This allows for normal ranges ("cut-offs") to be adapted to the variable risk profile of individual population groups [12, 13].

A common complaint about larger studies has been the lack of data on reducing mortality. In the meantime, though, a $60 \%$ reduction in CRC mortality has been demonstrated for the first time in patients who undergo an annual I-FOBT [14].

\section{Leucocyte markers}

Since colorectal neoplasia is characterised by only intermittent bleeding and thus hemoglobin does not make for an ideal marker, leucocyte proteins (calprotectin, lactoferrin) have been proposed as markers since the mid1990s, because they migrate from the surrounding neoplastic and inflammatory tissue to the intestinal lumen [15]. Calprotectin and lactoferrin are proteins of about $60 \mathrm{kDa}$ and constitute up to $60 \%$ of the total protein content of neutrophils. Due to their stability, they are ideal for detecting inflammatory cells in the stool. Its importance in initial and longitudinal diagnoses of inflammatory intestinal diseases has been confirmed repeatedly in numerous studies and is now uncontested [16] (Overview in 17). Especially with a view to increasing sensitivity further, particularly with respect to adenomas, the use of these fecal tests also seemed a reasonable tool for detecting colorectal cancer early. While it is true that the sensitivity levels of $63-90 \%$ for carcinomas and $26-80 \%$

Table 1 Overview of randomised studies regarding the use of guaiac hemoccult tests in screening for colorectal cancer.

\begin{tabular}{|c|c|c|c|c|c|c|c|c|}
\hline Author & Participant & $\begin{array}{l}\text { Age } \\
\text { (years) }\end{array}$ & $\begin{array}{l}\text { Duration } \\
\text { (years) }\end{array}$ & $\begin{array}{l}\text { Screening } \\
\text { interval } \\
\text { (years) }\end{array}$ & $\begin{array}{l}\text { Sensitivity } \\
\text { for CRC } \\
(\%)\end{array}$ & $\begin{array}{l}\text { PPV for CRC } \\
(\%)\end{array}$ & $\begin{array}{l}\text { Reduction in } \\
\text { CRC mortality } \\
(\%)\end{array}$ & $\begin{array}{l}\text { Compliance } \\
(\%)\end{array}$ \\
\hline Mandel et al. 1993 [6] & 15,570 & $50-80$ & 13 & 1 & 92 & 2.2 & 33 & 75 \\
\hline Kewenter et al. 1994 [36] & 33,884 & $60-64$ & 2 & 2 & 81 & $4.2-5.0$ & 12 & 63 \\
\hline Hardcastle et al. 1996 [37] & 75,253 & $45-74$ & 7.8 & 2 & 64 & $11(9.9-11.9)$ & 15 & 53 \\
\hline Kronborg et al. 1996 [38] & 30,967 & $45-75$ & 10 & 2 & 46 & $10.2-17.7$ & 18 & 67 \\
\hline
\end{tabular}

CRC: colorectal cancer; PPV: positive predictive value. 


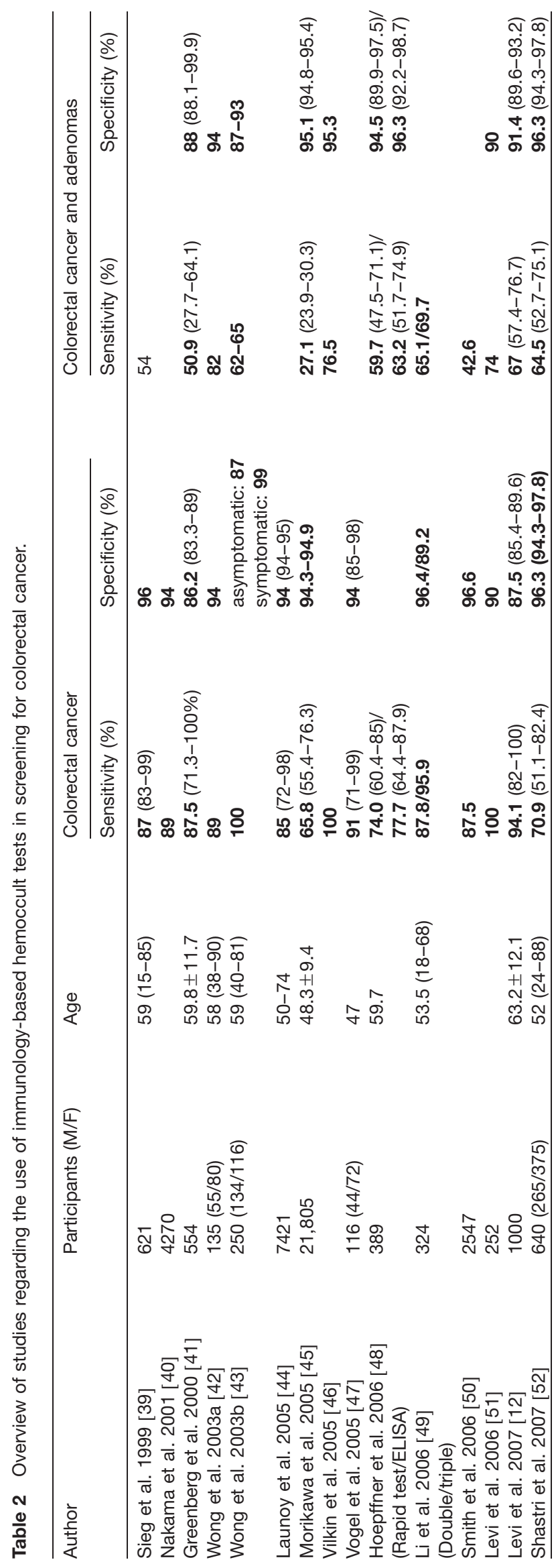


Table 3 Overview of studies regarding the use of leucocyte markers in screening for colorectal cancer (adapted from Haug and Brenner, 2005 [60]).

\begin{tabular}{|c|c|c|c|c|c|c|c|}
\hline \multirow[t]{2}{*}{ Author } & \multirow[t]{2}{*}{ Marker } & \multicolumn{3}{|c|}{ Study population (number, age) } & \multicolumn{2}{|c|}{ Sensitivity (95\% Cl) (\%) } & \multirow{2}{*}{$\begin{array}{l}\text { Specificity } \\
(95 \% \text { Cl) (\%) }\end{array}$} \\
\hline & & CRC & Adenomas & Control & $\mathrm{CRC}$ & Adenomas & \\
\hline Dubrow et al. 1992 [53] & Lysozyme & $\begin{array}{l}n=23 \\
66 y .\end{array}$ & - & $\begin{array}{l}n=39 \\
68 \mathrm{y}\end{array}$ & $43(23-66)$ & - & $69(52-83)$ \\
\hline Roseth et al. 1993 [15] & Calprotectin & $\begin{array}{l}n=40 \\
68 y .\end{array}$ & $\begin{array}{l}n=40 \\
68 y .\end{array}$ & $\begin{array}{l}n=64 \\
61 \mathrm{y} .\end{array}$ & 94 (84-99) & $80(64-91)$ & $73(61-84)$ \\
\hline Kronborg et al. 2000 [54] & Calprotectin & $\begin{array}{l}\mathrm{n}=23 \\
\text { n.a. }\end{array}$ & $\begin{array}{l}\mathrm{n}=203 \\
\text { n.a. }\end{array}$ & $\begin{array}{l}\mathrm{n}=58 \\
\mathrm{n} . \mathrm{a}\end{array}$ & $74(52-90)$ & $43(30-50)$ & $67(54-79)$ \\
\hline Johne et al. 2001 [55] & Calprotectin & $\begin{array}{l}n=177 \\
70 y\end{array}$ & - & $\begin{array}{l}n=145 \\
63 y\end{array}$ & $\begin{array}{l}\text { asymptomatic: } \\
64(44-81) \\
\text { symptomatic: } \\
87 \text { (81-92) }\end{array}$ & - & $67(59-74)$ \\
\hline Kristinsson et al. 2001 [56] & Calprotectin & $\begin{array}{l}\mathrm{n}=5 \\
\text { n.a. }\end{array}$ & $\begin{array}{l}n=73 \text {, } \\
\text { n.a. }\end{array}$ & $\begin{array}{l}n=114 \\
\text { n.a. }\end{array}$ & $80(28-99)$ & $56(23-66)$ & $47(38-57)$ \\
\hline Tibble et al. 2001 [57] & Calprotectin & $\begin{array}{l}n=62 \\
68 y .\end{array}$ & $\begin{array}{l}n=29 \text {, } \\
\text { n.a. }\end{array}$ & $\begin{array}{l}n=96 \\
41 y .\end{array}$ & $90(80-96)$ & $55(44-74)$ & $72(62-81)$ \\
\hline Limburg et al. 203 [58] & Calprotectin & $\begin{array}{l}\mathrm{n}=3 \\
\text { n.a. }\end{array}$ & $\begin{array}{l}\mathrm{n}=94 \\
\text { n.a. }\end{array}$ & $\begin{array}{l}\mathrm{n}=315 \\
\text { n.a. }\end{array}$ & - & $37(28-48)$ & 63 \\
\hline Hoff et al. 2004 [59] & Calprotectin & $\begin{array}{l}n=12, \\
\text { n.a. }\end{array}$ & $\begin{array}{l}\mathrm{n}=787 \\
\text { n.a. }\end{array}$ & $\begin{array}{l}n=1518 \\
\text { n.a. }\end{array}$ & $63(35-85)$ & $26(2-29)$ & 76 (74-78) \\
\hline
\end{tabular}

CRC: colorectal cancer; n.a.: not available.

for adenomas, as identified in eight studies (Table 3), are comparable to those of I-FOBTs, the specificity of $47-76 \%$, however, has been shown to be unacceptable for cost-efficient screening due to the follow-up costs resulting from false positive diagnoses.

\section{M2-PK}

The reduced ability to meet energy needs through the glycolytic breakdown of glucose is considered specific to tumour cells and is the result of a dimeric pyruvate kinase
(M2-PK) that is increasingly formed during malignant cell transformation. The detection of M2-PK in the stool, therefore, was initially seen as a new tumour-specific marker for malignant processes in the intestinal tract. Retrospective studies, at first for small populations, did identify sensitivity rates of $73 \%(60-84 \%)$, but, similar to calprotectin, this was obtained at the expense of specificity, which was at an unsatisfactory $78 \%$ (70-84\%); these findings were confirmed in subsequent prospective studies by various working groups with larger patient populations (Table 4) [18]. Own studies [19, 20], as well as those by other authors [21], point to positive test

Table 4 Overview of studies regarding the use of M2PK in screening for colorectal cancer (adapted from Haug and Brenner, 2005 [60]).

\begin{tabular}{|c|c|c|c|c|c|c|c|}
\hline \multirow[t]{2}{*}{ Author } & \multirow[t]{2}{*}{ Design } & \multirow[t]{2}{*}{ Participants (M/F) } & \multirow[t]{2}{*}{ Age } & \multicolumn{2}{|l|}{ Sensitivity (\%) } & \multicolumn{2}{|l|}{ Specificity (\%) } \\
\hline & & & & CRC & Adenoma & $\mathrm{CRC}$ & Adenoma \\
\hline $\begin{array}{l}\text { Hardt et al. } \\
2003[61]\end{array}$ & $\begin{array}{l}\text { Monocentre, } \\
\text { retrospective }\end{array}$ & $78(58 / 29)$ & 68.2 & 69 & 50 & n.a. & n.a. \\
\hline $\begin{array}{l}\text { Hardt et al. } \\
2004 \text { [18] }\end{array}$ & $\begin{array}{l}\text { Monocentre, } \\
\text { retrospective }\end{array}$ & 204 (n.a) & n.a. & 73.8 (60-84) & n.a. & 78 (70-84) & n.a. \\
\hline $\begin{array}{l}\text { Naumann et al. } \\
2004 \text { [62] }\end{array}$ & $\begin{array}{l}\text { Multicentre, } \\
\text { prospective }\end{array}$ & 232 & n.a. & 85 & 37 & n.a. & n.a. \\
\hline $\begin{array}{l}\text { Vogel et al. } 2005 \\
\text { [47] }\end{array}$ & $\begin{array}{l}\text { Multicentre, } \\
\text { prospective }\end{array}$ & $138(61 / 77)$ & 58 & 77 & 48 & 72 & n.a. \\
\hline $\begin{array}{l}\text { Shastri et al. } 2006 \\
\text { [19] }\end{array}$ & $\begin{array}{l}\text { Multicentre, } \\
\text { prospective }\end{array}$ & 317 (152/165) & 56 & 81 & 26 & 71 & 71 \\
\hline $\begin{array}{l}\text { Tonus et al. } 2006 \\
\text { [63] }\end{array}$ & $\begin{array}{l}\text { Monocentre, } \\
\text { retrospective }\end{array}$ & $96(54 / 42)$ & 66 & 78 & n.a. & 93 & 93 \\
\hline $\begin{array}{l}\text { Haug et al. } 2007 \\
{[64]}\end{array}$ & $\begin{array}{l}\text { Monocentre, } \\
\text { retrospective }\end{array}$ & 917 (n.a.) & $50-70$ & $\begin{array}{l}\text { Colon: } 85 \text { (65-96) } \\
\text { Rectum: } 56 \text { (76-81) }\end{array}$ & n.a. & n.a. & n.a. \\
\hline $\begin{array}{l}\text { Shastri et al. } 2007 \\
\text { [13] }\end{array}$ & $\begin{array}{l}\text { Multicentre, } \\
\text { prospective }\end{array}$ & $640(265 / 375)$ & $\begin{array}{l}52 \\
(24-88)\end{array}$ & $70.9(57.1-82.4)$ & $\begin{array}{l}30.4 \\
(19.9-42.7)\end{array}$ & 73.8 (69.8-77.6) & n.a. \\
\hline
\end{tabular}
n.a.: not available. 
results in patients suffering from chronic-inflammatory intestinal diseases in relation to inflammatory activity of up to $100 \%$, which disproves the propagated specificity of this test for neoplastic changes beyond any doubt [20, 22].

\section{Molecular markers}

The scientific basis for the concept of genetic fecal tests originated with Fearon and Vogelstein, who described molecular changes as an adenoma-to-carcinoma sequence of colorectal cancer at the end of the 1980s
[23] (Figure 1). According to this, up to $90 \%$ of all carcinomas exhibit mutations in the tumour suppressor gene APC [24], 40-50\% mutations in the oncogene K-ras [25] and 50-60\% mutations in the p53 tumour suppressor gene [26]. Furthermore, about $50 \%$ of all colorectal carcinomas are characterised by the deactivation of a tumour supressor gene on chromosome 18q, which has not yet been identified definitively [27]. Given how common they are, primarily APC, K-ras and p53 were initially seen as promising new tumour markers [28, 29]. The majority of publications, therefore, focused on detecting K-ras mutations at first. The APC gene is almost an ideal candidate gene, as it represents the first

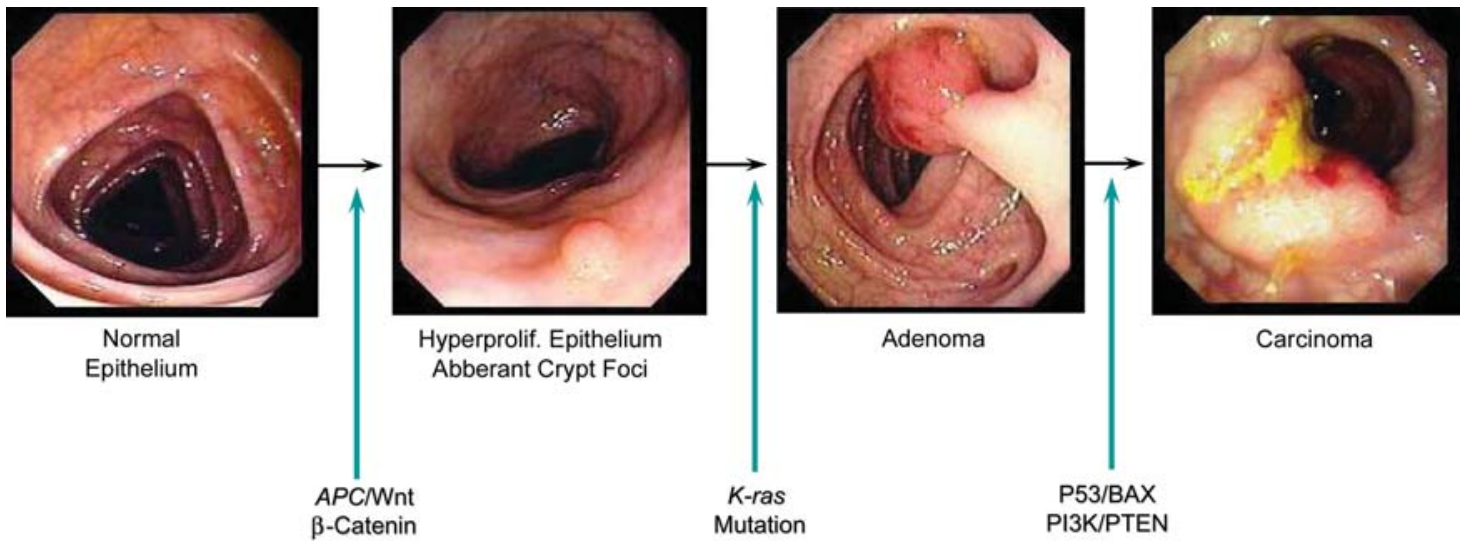

COX-2, mPGES $\hat{\imath}, 15-P G-D H ~ \Uparrow$

Figure 1 Adenoma-to-carcinoma sequence of colorectal cancer and the mutations occurring in the process.

Table 5 Detection of individual DNA mutations in the stool in patients with colorectal cancer (adapted from Haug and Brenner 2005 [60]).

\begin{tabular}{|c|c|c|c|c|c|c|c|}
\hline \multirow[t]{2}{*}{ Author } & \multirow[t]{2}{*}{ Marker } & \multicolumn{3}{|c|}{ Study population (number, age) } & \multicolumn{2}{|c|}{ Sensitivity $(95 \% \mathrm{Cl})(\%)$} & \multirow{2}{*}{$\begin{array}{l}\text { Specificity } \\
(95 \% \text { Cl) (\%) }\end{array}$} \\
\hline & & CRC & Adenomas & Check & $\mathrm{CRC}$ & Adenomas & \\
\hline $\begin{array}{l}\text { Ratto et al. } 1996 \\
\text { [65] }\end{array}$ & K-ras & $\begin{array}{l}n=25 \\
61 y .\end{array}$ & - & $n=11$ & $40(21-61)$ & - & $100(72-100)$ \\
\hline $\begin{array}{l}\text { Villa et al. } 1996 \\
\text { [66] }\end{array}$ & K-ras & $\begin{array}{l}n=5 \\
62 y .\end{array}$ & $\begin{array}{l}\mathrm{n}=42 \\
59 \mathrm{y} .\end{array}$ & $\begin{array}{l}\mathrm{n}=46 \\
50 y .\end{array}$ & $80(28-99)$ & $29(16-45)$ & 96 (85-99) \\
\hline $\begin{array}{l}\text { Puig et al. } 2000 \\
\text { [67] }\end{array}$ & K-ras & $\begin{array}{l}\mathrm{n}=11 \\
\text { n.a. }\end{array}$ & $\begin{array}{l}n=22 \\
\text { n.a. }\end{array}$ & $\begin{array}{l}\mathrm{n}=30, \text { n.a. } \\
25 \text { pathol. } \\
\text { controls }\end{array}$ & $55(23-83)$ & $27(11-50)$ & $100(88-100)$ \\
\hline $\begin{array}{l}\text { Wan et al. } 2004 \\
\text { [68] }\end{array}$ & K-ras & $\begin{array}{l}n=23 \\
69 y .\end{array}$ & $\begin{array}{l}\mathrm{n}=20 \\
\text { n.a. }\end{array}$ & $\begin{array}{l}\mathrm{n}=20 \\
\text { n.a. }\end{array}$ & $56(34-77)$ & $30(12-54)$ & $95(75-100)$ \\
\hline $\begin{array}{l}\text { Traverso et al. } \\
2002 \text { [30] }\end{array}$ & $\mathrm{APC}$ & $\begin{array}{l}n=28 \\
53 y .\end{array}$ & $\begin{array}{l}n=18 \\
63 y .\end{array}$ & $\begin{array}{l}n=28 \\
53 y .\end{array}$ & $61(41-79)$ & $50(26-74)$ & $100(88-100)$ \\
\hline $\begin{array}{l}\text { Traverso et al. } \\
2002 \text { [31] }\end{array}$ & BAT26 & $\begin{array}{l}n=46 \\
n \cdot a\end{array}$ & $\begin{array}{l}n=69 \\
\text { n.a. }\end{array}$ & $\begin{array}{l}\mathrm{n}=19 \\
\text { n.a. }\end{array}$ & $37(23-52)$ & 0 & $100(82-100)$ \\
\hline $\begin{array}{l}\text { Müller et al. } 2004 \\
\text { [69] }\end{array}$ & $\begin{array}{l}\text { SFRP2 } \\
\text { methylation }\end{array}$ & $\begin{array}{l}\mathrm{n}=13 \\
57 \mathrm{y} .\end{array}$ & - & $\begin{array}{l}\mathrm{n}=13 \\
49 y\end{array}$ & 77 (46-95) & - & $77(46-95)$ \\
\hline $\begin{array}{l}\text { Loktionov et al. } \\
1998 \text { [70] }\end{array}$ & SDNAI & $\begin{array}{l}\mathrm{n}=17 \\
69 \mathrm{y} .\end{array}$ & - & $\begin{array}{l}n=16 \\
68 y\end{array}$ & $100(80-100)$ & - & $81(54-96)$ \\
\hline $\begin{array}{l}\text { Boynton et al. } \\
2003[71]\end{array}$ & $\begin{array}{l}\text { DNA } \\
\text { integrity }\end{array}$ & $\begin{array}{l}\mathrm{n}=27 \\
\mathrm{n} . \mathrm{a}\end{array}$ & - & $\begin{array}{l}\mathrm{n}=77 \\
\text { n.a. }\end{array}$ & $56(35-75)$ & - & $97(91-100)$ \\
\hline
\end{tabular}

Cl: confidence interval; DIA: DNA integrity assay; L-DNA: Iong-DNA; MSI: microsatellite instability; n.a.: not available. 
Table 6 Detection of combined DNA mutations in the stool in patients with colorectal cancer (adapted from Haug and Brenner, $2005[60])$.

\begin{tabular}{|c|c|c|c|c|c|c|c|}
\hline \multirow[t]{2}{*}{ Author } & \multirow[t]{2}{*}{ Marker } & \multicolumn{3}{|c|}{ Study population (number, Age) } & \multicolumn{2}{|c|}{ Sensitivity (95\% Cl) (\%) } & \multirow{2}{*}{$\begin{array}{l}\text { Specificity } \\
(95 \% \text { Cl) (\%) }\end{array}$} \\
\hline & & CRC & Adenomas & Control & CRC & Adenomas & \\
\hline $\begin{array}{l}\text { Ahlquist et al. } \\
2000 \text { [3] }\end{array}$ & $\begin{array}{l}\text { K-ras } \\
P 53 \\
A P C \\
\text { BAT26 } \\
\text { L-DNA }\end{array}$ & $\begin{array}{l}n=22 \\
70 y\end{array}$ & $\begin{array}{l}n=11 \\
73 y\end{array}$ & $\begin{array}{l}n=28 \\
68 \mathrm{y}\end{array}$ & $\begin{array}{l}91(71-99) \\
\text { Independent } \\
\text { of stage }\end{array}$ & $82(48-98)$ & $93(77-99)$ \\
\hline $\begin{array}{l}\text { Koschiji et al. } \\
2002 \text { [72] }\end{array}$ & $\begin{array}{l}\text { K-ras } \\
A P C\end{array}$ & $\begin{array}{l}n=41 \\
63 y\end{array}$ & - & $\begin{array}{l}n=15 \\
\text { n.a. }\end{array}$ & $88(74-96)$ & & $100(78-100)$ \\
\hline $\begin{array}{l}\text { Calistri et al. } \\
2003 \text { [73] }\end{array}$ & $\begin{array}{l}\text { K-ras } \\
P 53 \\
A P C \\
M S I \\
\text { I-DNA }\end{array}$ & $\begin{array}{l}n=53 \\
62 y\end{array}$ & - & $\begin{array}{l}\mathrm{n}=38 \\
71 \mathrm{y}\end{array}$ & $62(48-75)$ & & $97(86-100)$ \\
\hline $\begin{array}{l}\text { Tagore et al. } \\
2003 \text { [74] }\end{array}$ & $\begin{array}{l}\text { K-ras } \\
\text { P53 } \\
A P C \\
M S I \\
D I A\end{array}$ & $\begin{array}{l}n=52 \\
64 y\end{array}$ & $\begin{array}{l}n=28 \\
61 y\end{array}$ & $\begin{array}{l}n=212 \\
63 y\end{array}$ & $64(49-76)$ & $57(36-76)$ & $96(93-98)$ \\
\hline $\begin{array}{l}\text { Leung WK et al. } \\
2007 \text { [75] }\end{array}$ & $\begin{array}{l}\text { APC } \\
\text { ATM } \\
\text { MLH1 } \\
\text { SFRP2 } \\
\text { HLTFMGMT }\end{array}$ & $\begin{array}{l}n=20 \\
69 y\end{array}$ & $\begin{array}{l}n=30 \\
70.5 y\end{array}$ & $\begin{array}{l}n=30 \\
70.5 y\end{array}$ & $75(50.9-91.3)$ & $68(46.5-85.1)$ & $90(73.5-97.9)$ \\
\hline
\end{tabular}

CI: confidence interval; DIA: DNA integrity assay; L-DNA: long-DNA; MSI: microsatellite instability; n.a.: not available.

step in the carcinogenesis of colorectal cancer (gatekeeper function) (Table 5).

When examining the stool for microsatellite instability in the BAT26 marker, microsatellite instability was detected in $37 \%$ of 46 proximally localised colorectal carcinomas. But none of the 19 proximally localised adenomas was identified [30, 31]. Such a low level of sensitivity for carcinomas and adenomas, therefore, indicates against the sole use of BAT26 as a molecular marker. But the low sensitivity level is not surprising, because only $15 \%$ of all colorectal carcinomas have a microsatellite instability (MSI). An incidence of $25-30 \%$ is assumed for proximally localised colorectal carcinomas. Similarly, microsatellite instability in sporadic colorectal carcinomas is often detected only once adenomas progress to carcinomas.

The sensitivity of molecular fecal tests can be increased by combining different molecular markers in a marker panel (Table 6). For example, Ahlquist et al. [32] were the first to use a panel of five markers for patients where colonoscopy had confirmed the presence of colorectal cancer and/or adenomas $>1 \mathrm{~cm}$, as compared to a control group for whom colonoscopy had yielded no pathological findings. For the study, 15 defined mutations were examined in the genes APC (4 times), p53 (8 times) and $\mathrm{K}$-ras (3 times), as were microsatellite instability (BAT26) and L-DNA (Long-DNA).

Table 7 Comparison of old and new fecal tests in screening for colorectal cancer.

\begin{tabular}{|c|c|c|c|c|c|c|}
\hline \multirow[t]{2}{*}{ Marker } & \multicolumn{2}{|c|}{ Colorectal carcinoma (\%) } & \multirow{2}{*}{$\begin{array}{l}\text { Adenomas (\%) } \\
\text { Sensitivity }\end{array}$} & \multicolumn{2}{|c|}{ Adenomas + CRC (\%) } & \multirow[t]{2}{*}{ Costs $(€)$} \\
\hline & Sensitivity & Specificity & & Sensitivity & Specificity & \\
\hline G-FOBT & $26(13-39)$ & $88-98$ & 1222 & $22-34$ & $86-96$ & $0.50-1$ \\
\hline I-FOBT & $66-100$ & $87-99$ & $20-30$ & $45-80$ & $88-96$ & $\begin{array}{l}\text { Rapid tests } 5-8 \\
\text { ELISAs 15-22 }\end{array}$ \\
\hline Calprotectin & $63-90$ & $47-99$ & $26-56(80)$ & & & $20-25$ \\
\hline M2-PK & $69-85$ & $65-78$ & $26-50$ & $55-74$ & $62-78$ & $25-30$ \\
\hline DNA-individual & 40.56 & $77-100$ & 2750 & n.a. & n.a. & $150-250$ \\
\hline DNA-combined & $88(74-96)$ & $90-100$ & $57-82$ & n.a. & n.a. & $300-400$ \\
\hline
\end{tabular}

n.a.: not available. 
Thanks to the panel used it was possible to diagnose $91 \%$ of all colorectal carcinomas and $82 \%$ of all adenomas. Specificity was $93 \%$ (95\% Cl $76-99 \%)$. When the K-ras marker was excluded, sensitivity was $91 \%$ (95\%-Cl: $71-99 \%)$ for colorectal cancer and $73 \%$ (95\%-Cl: $39-94 \%)$ for adenomas with a specificity of 100\% (95\%-Cl: 88-100\%). The positive predictive value, with K-ras being excluded, was $100 \%$; the negative predictive value was $85 \%$ [Overview in 33,34 ].

The findings from small patient populations so far have shown a sensitivity of molecular fecal tests of up to $90 \%$ in detecting colorectal cancer and, therefore, might be more sensitive and more specific than all other tests available thus far. However, the complicated sample preparation, the costs of staff and equipment and the resulting overall costs of $€ 300-€ 400$ per test are the reasons why this approach is not realistic for colorectal screening at this point [35].

\section{Conclusion}

The G-FOBT has been a fixed element in statutory early cancer screening in Germany since the end of the 1970s. Its benefit has been proved repeatedly in a variety of large-scale multicentre randomised studies. Still, due to its poor sensitivity, this test is of limited use.

The development of immunological tests to detect occult stool in the mid-1990s marked an important step towards improving sensitivity, specificity and patient compliance. I-FOBTs have been classified as more costefficient tests in the prevention of colorectal cancer in Japan and the United States.

By contrast, neither the detection of neutrophil markers, nor of M2-PK in the stool has met initial expectations due to insufficient specificity and the resulting follow-up costs.

Molecular markers are the way of the future. They produce sensitivity rates of $62-91 \%$ for colorectal cancer and $26-73 \%$ for adenomas, with a specificity of 93-100\%. They are limited, though, due to the expenditure in terms of staff and equipment and, thus, the resulting costs (Table 7 ).

\section{Acknowledgement}

This work was supported by the Else Kröner-Fresenius-Foundation, Bad Homburg (Germany).

\section{References}

1. Ferlay J, Bray F, Pisani P, Parkin DM. GLOBOCAN 2000: cancer incidence, mortality and prevalence worldwide, version 1.0. IARC Cancer Base 5. Lyon: IARC, 2001, http://wwwdep.iarc.fr/globocan/globocan.html.

2. Schneider AR, Caspary WF. Diagnosis of colorectal carcinoma. An update. Radiologe 2003;43:105-12.

3. Ahlquist DA, McGill DB, Fleming JL, Schwartz S, Wieand HS, Rubin J, et al. Patterns of occult bleeding in asymptomatic colorectal cancer. Cancer 1989;63:1826-30.

4. Macrae FA, St. John DJ. Relationship between patterns of bleeding and hemoccult sensitivity in patients with colorectal cancers or adenomas. Gastroenterology 1982;82:891-8.

5. Lieberman DA, Weiss DG. Veterans Affairs Cooperative Study Group 380. One-time screening for colorectal cancer with combined fecal occult-blood testing and examination of the distal colon. N Engl J Med 2001;345:555-60.

6. Mandel JS, Bond JH, Church TR, Snover DC, Bradley GM, Schuman LM, et al. Reducing mortality from colorectal cancer by screening for fecal occult blood. $N$ Engl $\mathrm{J}$ Med 1993;328:1365-71.

7. Winawer S, Fletcher R, Rex D, Bond J, Burt R, Ferrucci J, et al. Gastrointestinal Consortium Panel. Colorectal cancer screening and surveillance: Clinical guidelines and rationale - Update based on new evidence. Gastroenterology 2003; 124:544-60.

8. Ransohoff DF, Lang CA. Screening for colorectal cancer with the fecal occult blood test: a background paper. American College of Physicians. Ann Intern Med 1997;126: 811-22.

9. Mandel JS, Church TR, Bond JH, Ederer F, Geisser MS, Mongin SJ, et al. The effect of fecal occult-blood screening on the incidence of colorectal cancer. N Engl J Med 2000; 343:1603-7.

10. Rozen P, Knaani J, Samuel Z. Eliminating the need for dietary restrictions when using a sensitive guaiac fecal occult blood test. Dig Dis Sci 1999;44:756-60.

11. Cole SR, Young GP. Effect of dietary restriction on participation in faecal occult blood test screening for colorectal cancer. Med J Aust 2001;175:195-8.

12. Levi Z, Rozen P, Hazazi R, Vilkin A, Waked A, Maoz E, et al. A quantitative immunochemical fecal occult blood test for colorectal neoplasia. Ann Intern Med 2007;146:244-55.

13. Shastri YM, Stein J. Quantitative immunochemical fecal occult blood test for diagnosing colorectal neoplasia. Ann Intern Med 2007;147:522-3.

14. Saito H. Screening for colorectal cancer: current status in Japan. Dis Colon Rectum 2000;43:S78-84.

15. Roseth AG, Kristinsson J, Fagerhol MK, Schjonsby H, Aadland $\mathrm{E}$, Nygaard $\mathrm{K}$, et al. Faecal calprotectin: a novel test for the diagnosis of colorectal cancer? Scand J Gastroenterol 1993;28:1073-6.

16. Summerton CB, Longlands MG, Wiener K, Shreeve DR. Faecal calprotectin: a marker of inflammation throughout the intestinal tract. Eur J Gastroenterol Hepatol 2002;14: $841-5$.

17. Vermeire S, Van Assche G, Rutgeerts P. Laboratory markers in IBD: useful, magic, or unnecessary toys? Gut 2006;55: 426-31.

18. Hardt PD, Mazurek S, Toepler M, Schlierbach P, Bretzel RG, Eigenbrodt E, et al. Faecal tumour M2 pyruvate kinase: a new, sensitive screening tool for colorectal cancer. $\mathrm{Br} J$ Cancer 2004;91:980-4.

19. Shastri YM, Naumann M, Oremek GM, Hanisch E, Rösch $\mathrm{W}$, Mössner J, et al. Prospective multicenter evaluation of fecal tumor pyruvate kinase type M2 (M2-PK) as a screening biomarker for colorectal neoplasia. Int J Cancer 2006;119: 2651-6.

20. Shastri YM, Stein J. Fecal tumor M2 pyruvate kinase is not a specific biomarker for colorectal cancer screening. World J Gastroenterol 2007;13:2769-70.

21. Walkowiak J, Banasiewicz T, Krokowicz P, Hansdorfer-Korzon R, Drews M, Herzig KH. Fecal pyruvate kinase (M2-PK): 
a new predictor for inflammation and severity of pouchitis. Scand J Gastroenterol 2005;40:1493-4.

22. Shastri YM, Stein J. New faecal tests for colorectal cancer screening: is tumor pyruvate kinase M2 one of the options? Br J Cancer 2007;97:1595-6.

23. Fearon ER, Cho KR, Nigro JM, Kern SE, Simons JW, Ruppert JM, et al. Identification of a chromosome $18 \mathrm{q}$ gene that is altered in colorectal cancers. Science 1990;247:49-56.

24. Kinzler KW, Vogelstein B. Lessons from hereditary colorectal cancer. Cell 1996;87:159-70.

25. Bos JL. Ras oncogenes in human cancer: a review. Cancer Res 1989;49:4682-9.

26. Boland CR, Sato J, Appelman HD, Bresalier RS, Feinberg AP. Microallelotyping defines the sequence and tempo of allelic losses at tumour suppressor gene loci during colorectal cancer progression. Nat Med 1995;1:902-9.

27. Vogelstein B, Fearon ER, Hamilton SR, Kern SE, Preisinger AC, Leppert M, et al. Genetic alterations during colorectaltumor development. N Engl J Med 1998;319:525-32.

28. Eguchi S, Kohara N, Komuta K, Kanematsu T. Mutations of the p53 gene in the stool of patients with resectable colorectal cancer. Cancer 1996;77:1707-10.

29. Frattini M, Balestra D, Pilotti S, Bertario L, Pierotti MA. Tumor location and detection of k-ras mutations in stool from colorectal cancer patients. J Natl Cancer Inst 2003;95: 72-3.

30. Traverso G, Shuber A, Levin B, Johnson C, Olsson L, Schoetz DR Jr, et al. Detection of APC mutations in fecal DNA from patients with colorectal tumors. $\mathrm{N}$ Engl $\mathrm{J}$ Med 2002;346:311-20.

31. Traverso G, Shuber A, Olsson L, Levin B, Johnson C, Hamilton SR, et al. Detection of proximal colorectal cancers through analysis of faecal DNA. Lancet 2002;359:403-4.

32. Ahlquist DA, Skoletsky JE, Boynton KA, Harrington JJ, Mahoney DW, Pierceall WE, et al. Colorectal cancer screening by detection of altered human DNA in stool: feasibility of a multitarget assay panel. Gastroenterology 2000;119: 1219-27.

33. Arnold CN, Blum HE. Colon cancer: molecular markers. Dtsch Med Wochenschr 2005;130:880-2.

34. Davies RJ, Miller R, Coleman N. Colorectal cancer screening: prospects for molecular stool analysis. Nat Rev Cancer 2005;5:199-209.

35. Song K, Fendrick AM, Ladabaum U. Fecal DNA testing compared with conventional colorectal cancer screening methods: a decision analysis. Gastroenterology 2004;126: 1270-9.

36. Kewenter J, Björk S, Haglind E, Smith L, Svanvik J, Ahren C. Screening and rescreening for colorectal cancer. A controlled trial of fecal occult blood testing in 27,700 subjects. Cancer 1988;62:645-51.

37. Hardcastle JD, Chamberlain JO, Robinson MH, Moss SM, Amar SS, Balfour TW, et al. Randomised controlled trial of faecal-blood screening for colorectal cancer. Lancet 1996; 348:1472-7.

38. Kronborg O, Fenger C, Olsen J, Jorgensen OD, Sondergaard $\mathrm{O}$. Randomised study of screening for colorectal cancer with faecal-occult-blood test. Lancet 1996;348: 1467-71.

39. Sieg A, Thoms C, Lüthgens K, John MR, Schmidt-Gayk H. Detection of colorectal neoplasms by the highly sensitive hemoglobin-haptoglobin complex in feces. Int $\mathrm{J}$ Colorectal Dis 1999;14:267-71.

40. Nakama H, Zhang B, Zhang X. Evaluation of the optimum cut-off point in immunochemical occult blood testing in screening for colorectal cancer. Eur J Cancer 2001;37: 398-401.

41. Greenberg PD, Bertario L, Gnauck R, Kronborg O, Hardcastle JD, Epstein MS, et al. A prospective multicenter evaluation of new fecal occult blood tests in patients undergoing colonoscopy. Am J Gastroenterol 2000;95:1331-8.

42. Wong BC, Wong WM, Cheung KL, Tung TS, Rozen P, Young GP, et al. A sensitive guaiac fecal occult blood test is less useful than an immunochemical test for colorectal cancer screening in a Chinese population. Aliment Pharmacol Ther 2003;18:941-6.

43. Wong WM, Lam SK, Cheung KL, Tong TS, Rozen P, Young GP, et al. Evaluation of an automated immunochemical fecal occult blood test for colorectal neoplasia in a Chinese population. Cancer 2003;97:2420-4.

44. Launoy GD, Bertrand HJ, Berchi C, Talbourdet VY, Guizard $\mathrm{AV}$, Bouvier VM, et al. Evaluation of an immunochemical fecal occult blood test with automated reading in screening for colorectal cancer in a general average-risk population. Int J Cancer 2005;115:493-6.

45. Morikawa T, Kato J, Yamaji Y, Wada R, Mitsushima T, Shiratori Y. A comparison of the immunochemical fecal occult blood test and total colonoscopy in the asymptomatic population. Gastroenterology 2005;129:422-8.

46. Vilkin A, Rozen P, Levi Z, Waked A, Maoz E, Birkenfeld S, et al. Performance characteristics and evaluation of an automated-developed and quantitative, immunochemical, fecal occult blood screening test. Am J Gastroenterol 2005; 100:2519-25.

47. Vogel T, Driemel C, Hauser A, Hansmann A, Lange S, Jonas $M$, et al. Comparison of different stool tests for the detection of cancer of the colon. Dtsch Med Wochenschr 2005;130: 872-7.

48. Hoepffner N, Shastri YM, Hanisch E, Rosch W, Mossner J, Caspary WF, et al. Comparative evaluation of a new bedside faecal occult blood test in a prospective multicentre study. Aliment Pharmacol Ther 2006;23:145-54.

49. Li S, Wang H, Hu J, Li N, Liu Y, Wu Z, et al. New immunochemical fecal occult blood test with two-consecutive stool sample testing is a cost-effective approach for colon cancer screening: results of a prospective multicenter study in Chinese patients. Int J Cancer 2006;118:3078-83.

50. Smith A, Young GP, Cole SR, Bampton P. Comparison of a brush-sampling fecal immunochemical test for hemoglobin with a sensitive guaiac-based fecal occult blood test in detection of colorectal neoplasia. Cancer 2006;107:2152-9.

51. Levi Z, Hazazi R, Rozen P, Vilkin A, Waked A, Niv Y. A quantitative immunochemical faecal occult blood test is more efficient for detecting significant colorectal neoplasia than a sensitive guaiac test. Aliment Pharmacol Ther 2006;23: 1359-64.

52. Shastri YM, Yogesh Shastri, Povse N, Hoepffner N, Loitsch $\mathrm{S}$, Caspary WF, et al. Stein J. Prospective comparative evaluation of fecal tumor pyruvate kinase type M2(M2-PK) with a rapid bedside immunological test for screening of Colorectal neoplasia. Am J Gastroentero 2008; in press.

53. Dubrow R, Kim CS, Eldred AK. Fecal lysozyme: an unreliable marker for colorectal cancer. Am J Gastroenterol 1992; 87:617-21.

54. Kronborg O, Ugstad M, Fuglerud P, Johne B, Hardcastle J, Scholefield $\mathrm{JH}$, et al. Faecal calprotectin levels in a high risk population for colorectal neoplasia. Gut 2000;46:795-800.

55. Johne B, Kronborg O, Ton HI, Kristinsson J, Fuglerud P. A new fecal calprotectin test for colorectal neoplasia. Clinical results and comparison with previous method. Scand $\mathrm{J}$ Gastroenterol 2001;36:291-6. 
56. Kristinsson J, Nygaard K, Aadland E, Barstad S, Sauar J, Hofstad B, et al. Screening of first degree relatives of patients operated for colorectal cancer: evaluation of fecal calprotectin vs. hemoccult II. Digestion 2001;64:104-10.

57. Tibble J, Sigthorsson G, Foster R, Sherwood R, Fagerhol $M$, Bjarnason I. Faecal calprotectin and faecal occult blood tests in the diagnosis of colorectal carcinoma and adenoma. Gut 2001;49:402-8.

58. Limburg PJ, Devens ME, Harrington JJ, Diehl NN, Mahoney DW, Ahlquist DA. Prospective evaluation of fecal calprotectin as a screening biomarker for colorectal neoplasia. Am J Gastroenterol 2003;98:2299-305.

59. Hoff G, Grotmol T, Thiis-Evensen E, Bretthauer M, Gondal G, Vatn MH. Testing for faecal calprotectin (PhiCal) in the Norwegian Colorectal Cancer Prevention trial on flexible sigmoidoscopy screening: comparison with an immunochemical test for occult blood (FlexSure OBT). Gut 2004; 53:1329-33.

60. Haug U, Brenner $\mathrm{H}$. New stool tests for colorectal cancer screening: a systematic review focusing on performance characteristics and practicalness. Int J Cancer 2005;117: 169-76.

61. Hardt PD, Toepler M, Ngoumou B, Rupp J, Kloer HU. Measurement of fecal pyruvate kinase type M2 (tumor M2-PK) concentrations in patients with gastric cancer, colorectal cancer, colorectal adenomas and controls. Anticancer Res 2003;23:851-3.

62. Naumann M, Schaum B, Oremek GM, Hanisch E, Rösch W, Mössner J, et al. Faecal pyruvate kinase type M2 - a valid screening parameter for colorectal cancer? Preliminary results from a multicenter comparative study. Dtsch Med Wochenschr 2004;129:1806-7.

63. Tonus C, Neupert G, Sellinger M. Colorectal cancer screening by non-invasive metabolic biomarker fecal tumor M2PK. World J Gastroenterol 2006;12:7007-11.

64. Haug U, Rothenbacher D, Wente MN, Seiler CM, Stegmaier $\mathrm{C}$, Brenner $\mathrm{H}$. Tumour M2-PK as a stool marker for colorectal cancer: comparative analysis in a large sample of unselected older adults vs colorectal cancer patients. $\mathrm{Br} \mathrm{J}$ Cancer 2007:96:1329-34.

65. Ratto C, Flamini G, Sofo L, Nucera P, Ippoliti M, Curigliano $G$, et al. Detection of oncogene mutation from neoplastic colonic cells exfoliated in feces. Dis Colon Rectum 1996; 39:1238-44.

66. Villa E, Dugani A, Rebecchi AM, Vignoli A, Grottola A, Buttafoco $\mathrm{P}$, et al. Identification of subjects at risk for colorectal carcinoma through a test based on K-ras determination in the stool. Gastroenterology 1996;110:1346-53.

67. Puig P, Urgell E, Capella G, Sancho FJ, Pujol J, Boadas J, et al. A highly sensitive method for K-ras mutation detection is useful in diagnosis of gastrointestinal cancer. Int $\mathrm{J}$ Cancer 2000;85:73-7.

68. Wan J, Zhang ZQ, You WD, Sun HK, Zhang JP, Wang YH, et al. Detection of K-ras gene mutation in fecal samples from elderly large intestinal cancer patients and its diagnostic significance. World J Gastroenterol 2004;10:743-6.

69. Müller HM, Oberwalder M, Fiegl H, Morandell M, Goebel G, Zitt $\mathrm{M}$, et al. Methylation changes in faecal DNA: a marker for colorectal cancer screening? Lancet 2004;363: 1283-5.

70. Loktionov A, O'Neill IK, Silvester KR, Cummings JH, Middleton SJ, Miller R. Quantitation of DNA from exfoliated colonocytes isolated from human stool surface as a novel noninvasive screening test for colorectal cancer. Clin Cancer Res 1998;4:337-42.

71. Boynton KA, Summerhayes IC, Ahlquist DA, Shuber AP. DNA integrity as a potential marker for stool-based detection of colorectal cancer. Clin Chem 2003;49:1058-65.

72. Koshiji M, Yonekura Y, Saito T, Yoshioka K. Microsatellite analysis of fecal DNA for colorectal cancer detection. J Surg Oncol 2002;80:34-40.

73. Calistri D, Rengucci C, Bocchini R, Saragoni L, Zoli W, Amadori D. Fecal multiple molecular tests to detect colorectal cancer in stool. Clin Gastroenterol Hepatol 2003;1:377-83.

74. Tagore KS, Lawson MJ, Yucaitis JA, Gage R, Orr T, Shuber AP, et al. Sensitivity and specificity of a stool DNA multitarget assay panel for the detection of advanced colorectal neoplasia. Clin Colorectal Cancer 2003;3:47-53.

75. Leung WK, To KF, Man EP, Chan MW, Hui AJ, Ng SS, et al. Detection of hypermethylated DNA or cyclooxygenase-2 messenger RNA in fecal samples of patients with colorectal cancer or polyps. Am J Gastroenterol 2007;102:1070-6. 